sciendo Порівняльна професійна педагогіка 8(4)/2018 Comparative Professional Pedagogy 8(4)/2018

DOI: $10.2478 /$ rpp-2018-0052

Postgraduate Student, DMYTRO BIDYUK

Khmelnytskyi National University, Ukraine

Address: 11 Instytutdka St., Khmelnytskyi, 29016, Ukraine

E-mail: biduk.de@ukr.net

\title{
PROFESSIONAL TRAINING OF CHOREOGRAPHY STUDENTS IN EUROPEAN UNIVERSITIES
}

\begin{abstract}
The article deals with the analysis of professional training of choreography students in European universities. It is indicated that choreography education is a certain system of dancing training, which cultivates students' artistic, physical and technical skills necessary for the dancing profession, as well as develops their special knowledge. It is found that an indispensable component of learning is character and national dance. It is specified that the prospects of using foreign experience to modernize choreography education include different levels, namely the European level (an intensification of cooperation with international educational organizations, promotion of intercultural education and international relations through participation in cultural exchange programmes and international dance competitions and festivals), the national level (elaboration of appropriate legal and regulatory acts, design of national cultural and educational programmes for developing choreographic culture, introduction of new models of choreography training (theater dance, choreotherapy, modern dance), formulation of modern requirements for future specialists, allocation of budget on choreography development), the institutional level (administrative support of international scientific projects, introduction of appropriate strategies for developing choreographic industry, introduction of new courses, modernization of existing training programmes, introduction of innovative choreographic training programmes, creation of special programmes for students with special educational needs, Europeasation of lecture content, introduction of innovative elective modules at departments of choreography, organization of international workshops).
\end{abstract}

Keywords: choreography, choreography education, choreography student, European universities, professional training.

\section{INTRODUCTION}

Under the modern conditions, the development of choreography education is determined by integration, humanistic and information challenges. In Europe, the tendency to recognize choreography courses is becoming an important factor in involving children and young people in European culture in the process of developing European identity taking into account the national background. Awareness and understanding of the links between art and science give grounds for allocating a new, scientific and artistic paradigm that is choreography education.

Modern transformations in cultural paradigms result in dramatic changes in social self-affirmation of the individual and the shift towards developing his/her technical capabilities and skills to increase his/her "human qualities". In choreography education, this process is somewhat slow, but still develops. First of all, this relates to its most problematic 
sciendo Порівняльна професійна педагогіка 8(4)/2018 Comparative Professional Pedagogy 8(4)/2018

scientific component, namely research methodology in choreography and development of choreology. Secondly, modern dancing changes not only the range of expressive means, expanding their search due to non-dancing elements and synthesis of traditional movements in various types of choreographic art, but also affects techniques of choreographic work and principles of its stage existence, creating conditions for the emergence of new choreographic forms.

THE AIM OF THE STUDY

The main aim of the article is to analyze professional training of choreography students in European universities.

\section{THEORETICAL FRAMEWORK AND RESEARCH METHODS}

In scientific discourse, some theoretical and methodological aspects of choreography education, professional training of choreographers were considered by such scholars as W. Lawson, J. Parviainen, B. Sierra-Janik (aesthetic and art aspects of choreography education); A. Brudnowska, O. Chepalov, Z. Pędzich, D. Sharykov, M. Strzelecka, \& E. Szubstarska (the term "choreology", "choreotherapy", "choreotherapy" education); J. Dubaj, T. Hanna, A. Soczyńska \& M. Osipowicz, A. Zofia (methods and techniques of teaching choreographers).

The term "choreology" was first used by Rudolf and Joan Benesch, the inventors of Benesh notation or choreology that is a dance notation system used to document dance and other types of human movement. However, the term "choreology" later became more widely interpreted and now interpreted as a study of choreography (similar to musicology). The Great Dictionary of Foreign Languages (2003) interprets "choreology" as theory of dancing. Most post-Soviet researchers (N. Sargsian, V. Romm, O. Chepalov et al.) share similar views and suggest that the scientific and aesthetic system should be mainly mastered based on the consideration of various forms of human movement. O. Chepalov (2007) defines choreology as a science about dancing, which now required that its theoretical basis be expanded and research objects and the means of their linguistic embodiment be specified. D. Sharikov considers choreology as a universal science about theory, history and artistic practice of choreographic culture in general, as well as in the context of artistic culture and art studies, which greatly extends the limits of modern research.

Nowadays, art studies still do not single out choreology as a special branch of science. It, however, studies theory and history of choreography, scenic and everyday practice, ballet criticism, choreographic methods, choreographic system of organization and management in the ballet theater, ensembles, dance groups. In the UK, they have Trinity Laban Conservatoire of Music and Dance. Laban Dance Center, which offers a course in dance science (PhD thesis), creative practice in dance and synthesis of arts, a science about dance, dance pedagogy. In France, there is Le Conservatoire national supérieur de musique et de danse de Paris (National Superior Conservatory of Paris for Music and Dance) with researh faculty "Dance Performance: Classical and Modern Dance. Notation of Dance Movement" (Sharykov, 2013).

The above-mentioned aspects single out the problem areas in modern choreography education, which have not been properly studied yet.

While researching, such methods as analysis and synthesis, induction and deduction, systematization and generalization were used.

\section{RESULTS}

The research singled out the main trends and promising areas in the development of modern choreograpy education in the European educational space. In the modern 


\section{Sciendo Порівняльна професійна педагогіка 8(4)/2018 Comparative Professional Pedagogy 8(4)/2018}

European scientific discourse, choreography (its theory, history, practice, methods) and, in particular, choreology are represented in art studies and its scientific achievements are now systematized (gradually changing and being supplemented by conceptual framework) and scientifically promising. This opens new opportunities for improving professional training of future choreographers in the context of interdisciplinary and cross-cultural integration, the range of study on choreology in choreographic education, including new scientific fields (epistemology, kinetics, phenomenology, somatics, etc.); methodology of study on choreography training is based on the use of systematic approach; methodology of choreographers' professional training is based on the principle of "pluralism of dance", which allows one to acquire professional skills in different areas of dance techniques, styles and schools; introduction of somatic learning in choreography training, which is rather promising and necessary for further development of modern choreography; dynamics of choreography education as a sphere of cultural self-creation is an indicator of "ontological correlation" between spiritual values in society, their historical expedience and relevance, as well as its relation to universal culture.

Within the limits of choreology, ones studies the problems of choreotherapy, namely health improvement by means of dance. In Poland, it is represented by such scholars as A. Zofia, A. Brudnowska, W. Dubaj, Z. Pędzich. In the country, choreotherapy education is offered at the University of Humanities and Economics in Lódź through a course in rehabilitation of dancers and choreotherapy and at the University of Social Sciences in Lublin. Training programmes include theory and practice of dance therapy, analysis and observation of current specialists' activities, the main areas in psychotherapy, psychotherapeutic diagnostics, developmental psychology, experimental anatomy, psychopathology, ethics, etc. Thus, theoretical and most practical training allow students to acquire skills in different types of dance (classical, national and folk, ballroom and modern dance). Graduates obtain professional knowledge of music and its forms, composition of music, as well as the knowledge of rhythmics, costume design, scenography, art, acting, fitness, gymnastics, etc.

The European practice of professional training for future choreographers is based on the principles of "authors' schools", "dance pluralism", and "workshops", which contribute to developing professional skills in various areas of dance techniques, styles and schools. Professional training in European educational institutions is based on the freedom to choose one's style, school, technique, trend to create an individual style of creativity. Such famous personalities in the modern world of dance as J. Balanchine, M. Graham, M. Kenningham, P. Bausch, U. Forsyth) offered and offer their own choreographic technique, creative process and techniques for its implementation. Each of them in a certain way appreciated the dance culture of their time and embodied the corresponding reaction in their works, which in turn influenced the modern choreographic art.

The method of creating a new dance language not related to some outdated "content" and "ideological" connotations is a bodily phenomenon, which is understood as a study of simple physical actions and related kinesthetic sensations. The main theme of the dance becomes "here and now" presence of the body rooted in the empirical reality of everyday life. However, the absence of psychological and artistic "events" is offset by the awareness of the very movement as a physical and kinetic event. The dancer perceives the feelings and images of the movement, its meaning, quality, shape, texture, that is the visual and kinetic form. Modern American researchers believe that the movement reflects all forms of kinetic organization of the creative structure (Parviainen, 2002). 
sciendo Порівняльна професійна педагогіка 8(4)/2018 Comparative Professional Pedagogy 8(4)/2018

Despite that fact that dance is not less rational than conceptual thinking, all dancers are distinguished by the level of bodily knowledge, which is primarily perceived by verbal means. When it relates to non-verbal factors, the problem addressed by P. Bausch becomes significant: "I am less interested in how dancers move, more important is what forces them to move in this way" (Lawson, 2002).

Taking into account the fact that "modern dance becomes a way of non-verbal, plastic "comprehension", turning "to the body and the physical, tactile perception of the world", the search for new forms of movement have resulted in new approaches in movement education. One of the approaches reflecting the imminent qualitative changes in the attitude towards the body is somatic practice (Soczyńska, \& Osipowicz, 2009).

Particular attention should be paid to the methods and techniques of teaching choreography based on bodily experience at the institutional level. S. Fraleigh indicates that "the skill of the dancer is one of the forms of his/her knowledge, but one can speak of the kinetic component of intelligence as an aspect of the artist's skill" (Parviainen, 2002).

The introduction of somatic practices in choreography education is caused not only by mastering practical lessons in somatic disciplines, but also by integrating the principles of somatic education into dance practices. In the context of somatic disciplines and somatic learning, the term "embodiment" is used to describe the creation of a bright and "personalized" image. In choreographic practice, the embodiment involves all the participants into staging a multilevel process of materialization, which manifests itself in all means of expressiveness, peculiar to the specifics of such a spectacle. In this case, the embodiment is characterized by an extended interpretation and goes beyond physical characteristics of the movement suggested by the choreographer. The use of an image as a psychological activity that defines physical characteristics of an absent object or a dynamic event is at the heart of many somatic practices, since visualization is a powerful tool in combining processes of mind and body at the time of programming the "correct" (planned) action without excessive exhausting physical exercises. It is a modern multifunctional strategy in dance practices, which implies a conscious attitude towards breathing, general awareness of the body (a sense of vertical position and interdependent work of joints), a dynamic use of space.

The term "somatic" was first used by T. Hanna (1970), who developed a methodology for developing somatic thinking, which included providing sensory feedback, developing deliberately delayed attention, introducing movement education through internal experience rather than simulation. Somatic learning pays more importance to sensory awareness than movement. In the process of somatic learning, the ability to explore (analyze) and understand the meaning of internal sensations stimulates "sensory control". Sensory control enhances movement autonomy / self-control as the ability to self-organize movement from the inside, in contrast to the usual external factors such as teacher correction and mirror. Kinesthetic awareness is an effective practice for reprogramming neuromuscular "habits".

Many European universities (the Paris Conservatory, the Laban Centre for Movement and Dance, dance schools in Amsterdam, Vancouver, Berlin, etc.) widely use innovate methods, including ideokinesis (an approach to transforming movement skills with the help of kinetic aesthetic images used for obtaining specific muscle reactions), the Feldenkreis method, the Alexander technique, Body-Mind Centring. The use of these methods encourages students to engage in self-directed study and self-education and develop their internal awareness.

In Germany, the specificity of higher choreographic schools consists in a creative combination of modern dance, improvisation and classical dance, where the latter is the 
sciendo Порівняльна професійна педагогіка 8(4)/2018 Comparative Professional Pedagogy 8(4)/2018

leading element. Considerable attention is paid to additional disciplines such rhythmics, the principles of music theory, psychology and anatomy, the history of dance and music. German choreography students study dance as a holistic process. Improvisation is aimed at expressing one's individuality and, therefore, occupies a special place in the learning process. In this regard, art projects and trips are rather efficient and effective, since they enhance students' dance skills and expand their knowledge in the field of art. Students master the programmes developed by the leading choreographers. Educational practice is mostly provided at ballet troupes of local theaters. It should be noted that German artistic institutions closely cooperate with theaters, both local and national.

In the country, modern choreography education involves several graduate programmes, namely a bachelor programme in stage dance (Bachelorstudiengang Bühnentanz), a bachelor programme in dance pedagogy (Bachelor - Studiengang Tanzpädagogik), a master programme in choreography (Masterstudiengang Choreographie), a master programme in dance pedagogy (Master - Studiengang Tanzpädagogik). The master programme in dance pedagogy offered by Palucca University of Dance in Dresden should be considered in more detail. This programme requires preliminary special artistic, choreographic training or longterm dancing experience. It allows students to master the fundamental knowledge of dance pedagogy. The combination of theoretical training, in particular professional subjects and their practical application is an integral part of higher choreography education in Germany. Students can choose the profile themselves: either classical or contemporary choreography. Some disciplines (kinetics, methodology of approaches to the human body and movement, music, improvisation and composition) play an important role in training undergraduate students. The study of anatomy, physiology, traumatology, the history of dance and art, philosophy, aesthetic theory, drama and pedagogy, psychology form the basis of theoretical and scientific activities in Palucca University of Dance in Dresden. This master programme is designed for professional dancers who wish to obtain a diploma with a qualification of a lecturer in choreographic disciplines or a ballet dancer. It covers two years and upon its successful completion students receive a degree of Master of Arts (M.M.) in dance pedagogy (Palucca Hochschule für Tanz Dresden, 2018; Tanzplan Deutschland, 2018).

The John Neumieer Ballet School of the Hamburg State Opera is a modern set of rehearsal studios, ballet school and boarding school. The school was founded in 1978 with the aim to train young people from all over the world for a professional dance career. The curriculum includes all aspects of academic classical dance, for example, pas de deux (step of two), dance on pointe, classical and contemporary variations, and the Neymieer style. Classes devoted to the techniques of contemporary and stage dance are complemented by pilates and form part of the training. Strong emphasis is placed on choreographic composition classes. The academic programme includes a series of disciplines, namely anatomy, music theory and dance history. All classes are held at the Ballettzentrum Hamburg. Admission exams for schoolchildren are held annually in spring. Applicants are tested for physical abilities, artistic and improvisational skills, as well as the level of classical ballet technique according to their age. There are several levels of learning in the School: preparatory classes for children aged between 7 and 10; junior professional classes for children aged between 10 and 16; theater classes for adolescnets aged between 16 and 18 .

The most famous and popular dance choreographies in Germany are Palucca University of Dance in Dresden (Palucca Hochschule für Tanz Dresden), the University of Music and Theater Munich (the Hochschule für Musik und Theater München), the State 
School of Ballet and the School of Artistry in Berlin (Staatliche Ballettschule Berlin und Schule fur Artistik), Higher School of Music and Theater in Munich (Hochschule für Musik und Theater München), State Ballet School and School for Artistry in Berlin (Staatliche Ballettschule Berlin und Schule fur Artistik), Mannheim University of Music and Performing Arts (Staatliche Hochschule für Music und Darstellen de Kunst Mannheim), Ernst Bush Academy of Dramatic Arts in Berlin (Hochschule für Schauspielkunst Ernst Busch Berlin), Justus Liebig University Giessen (Justus-Liebig-Universität Gießen), The Cologne University of Music and Dance (Hochschule für Music und Tanz Köln) and Folkwang University of the Arts (Folkwang Universität Folkungen in Essen).

In Poland, the modernization of professional training for choreographers involves reorganization of old centers and creation of new ones for choreography education (child development centers, dance schools, choreography schools, cultural centers, dance studios and centers, dance clubs and contemporary dance sets, choreography clubs, dance courses, dance centers, ballet schools, studios, universities, academies, the Frederik Chopin University of Music), which are authorithed to independently solve content and organizational issues, develop and implement authors' programmes into in the education process. Modernization processes are characterized by a gradual transition from classical to contemporary dance and the emergence of the latest models of choreographic training (theater dance, choreotherapy, modern dance) (Strzelecka, \& Szubstarska, 2010).

It is found that the content of choreographers' higher professional education is modernized in accordance with the demands of society and requirements of the labour market. The curricula are updated in accordance with the innovative trends in training (degree courses). It must be noted that syllabi are most actively updated due to the introduction of new subjects containing intercultural, modern and therapeutic components.

Stanisław Staszic Higher School of Skills (Wyższa Szkoła Umiejętności im. Stanisława Staszica) deserves special attention since it is ranked 22th in Polish rankings (Wyższa Szkoła Umiejętności im. Stanisława Staszica w Kielcach, 2018). Students have many opportunities for scientific, cultural and physical development. They participate in various student organizations (student self-government, sports associations and scientific associations), publish their own newspapers, etc.

Higher School of Social Skills in Poznań (Wyższa Szkoła Umiejętności Społecznych w Poznaniu) founded in 1997 offers a classical modern of choreography training. The School hosts guests of the University of the Third Age, as well as pupils from lyceums in Poznan, Kuyavian-Pomeranian and Lodz Voivodeships. The School offers the opportunity to study in eight areas, which are accompanied by four faculties: art faculty, law and social communication faculty, dance faculty and non-resident faculty in Konin. Upon completing a 3-year course in dance, graduates obtain the right work in the following positions: a dance artist, a choreographer at dance music institutions, a journalist and an editor in specialized magazines, a dance animator and a manager in centers for dance and culture. The student must have a CEFR B2 level of a foreign language proficiency and know the relevant dance vocabulary so that he/she can cooperate with international partners (Wyższa Szkoła Umiejętności Społecznych w Poznaniu, 2018).

The Frederic Chopin Music University in Warsaw trains specialists in art and is the only higher education institution in Mazovian Voivodeship that integrates musical (rhythmics) and choreographic sciences. The University is entitled to award the degrees of Doctor of Arts and Doctor of Musical Arts in five areas (Uniwersytet Muzyczny Fryderyka Chopina w Warszawie, 2018). 
sciendo Порівняльна професійна педагогіка 8(4)/2018 Comparative Professional Pedagogy 8(4)/2018

\section{CONCLUSIONS}

Choreography education is a certain system of dancing training, which cultivates students' artistic, physical and technical skills necessary for the dancing profession, as well as develops their special knowledge. An indispensable component of learning is character and national dance. The following are the prospects of using foreign experience to modernize choreography education at different levels: at the European level - an intensification of cooperation with international educational organizations, promotion of intercultural education and international relations through participation in cultural exchange programmes and international dance competitions and festivals; at the national level - elaboration of appropriate legal and regulatory acts, design of national cultural and educational programmes for developing choreographic culture, introduction of new models of choreography training (theater dance, choreotherapy, modern dance), formulation of modern requirements for future specialists, allocation of budget on choreography development; at the institutional level - administrative support of international scientific projects, introduction of appropriate strategies for developing choreographic industry, introduction of new courses, modernization of existing training programmes, introduction of innovative choreographic training programmes, creation of special programmes for students with special educational needs, Europeasation of lecture content, introduction of innovative elective modules at departments of choreography, organization of international workshops.

Further research should be aimed at stuyding innovative experience in training future choreographers in the system of continuing choreographic education and improving the content and optimizing the structure of choreography education.

\section{REFERENCES}

1.Akademia Humanistyczno-Ekonomiczna $w$ Lodzi. (2018). Retrieved from http://www.ahe.lodz.pl.

2. Brudnowska, A. (2010). Taniec i choreoterapia jako sposób na poprawę jakości życia współczesnej polki. Nowiny Lekarskie, 79, 47-55.

3. Chepalov, O. (2007). Khoreolohiia - teoriia khoreohrafichnoho mystetstva (Perspektyvy stanovlennia u naukovii ta navchalnii praktytsi). Problemy suchasnosti: kultura, mystetstvo, pedahohika. Chastyna 2. Mystetstvoznavstvo, 7, 172-180.

4. Dubaj, W. (2005). Wplyw choreoterapii na równowagę ciała dzieci niestyszacych $i$ niedosłyszacych. Kraków: Zakład Taneczno-Muzycznych Form Ruchowych Akademii Wychowania Fizycznego w Krakowie.

5. Hanna, T. (1970). Bodies in revolt: a primer for somatic thinking. New York, NY: Holt, Rinehart and Winston.

6. Lawson, W. (2002). Interview with Pina Bausch. Retrieved from http: //ballet.co.uk/ magazines/yr_02/feb02/interview_bausch.htm.

7. Palucca Hochschule für Tanz Dresden. (2018). Retrieved from http: // www.palucca.eu.

8. Tanzplan Deutschland. (2018). Retrieved from http://www.tanzplan-deutschland.de/.

9. Parviainen, J. (2002). Bodily knowledge: epistemological reflections on dance. Dance Research Journal, 34 (1), 11-26.

10. Pędzich, Z. (2012). Choreoterapia. In L. Grzesiuk, \& H. Suszka (Eds.), Psychoterapia: podręcznik akademicki (pp. 553-565). Warszawa: Eneteia. 
11. Sharykov, D. I. (2013). Mystetstvoznavcha dystsyplina khoreolohiia yak fenomen khudozhnoi kultury. Visnyk NAKKKiM. Seriia "Mystetstvoznavstvo", 1, 113-117.

12. Sierra-Janik, B. (2011). Zachodnya zawodowa w zakresie dance. Warszawa: Instytut Muzyki i Tańca.

13. Soczyńska, A., \& Osipowicz, M. (2009). Autorski program z fakultetów tańca. Retrieved from http://www.edukator.org.pl/2010/autorski/program.pdf.

14. Strzelecka, M., \& Szubstarska, E. (2010). Choreoterapia - terapia tańcem $i$ ruchem. Retrieved from http://unicorn.org.pl

/user_files/pliki/I_Konferencja_Psychoonkologii_Praktycznej_BROSZURA.pdf

15. Uniwersytet Muzyczny Fryderyka Chopina w Warszawie. (2018). Retrieved from http://www.chopin.edu.pl/en/.

16. Wyższa Szkoła Nauk Społecznych w Lublinie. (2018). Retrieved from http://www.wsns.lublin.pl/.

17. Wyższa Szkoła Umiejętności im. Stanisława Staszica w Kielcach. (2018). Retrieved from http://www.wsu.kielce.pl/.

18. Wyższa Szkoła Umiejętności Społecznych w Poznaniu. (2018). Retrieved from http://wsus.pl/pl/kandydat.

19. Zofia, A. (2004). Główne aspekty choreoterapii klinicznej stosowanej w psychiatrii (refleksje własne na podstawie studiów literatury przedmiotu). In M. Knapik, \& W. A. Sacher (Eds.), Sztuka w edukacji i terapii (pp. 225-230). Kraków: Impuls. 